\title{
Exposure of hairdressing apprentices to airborne hazardous
} substances

\author{
Estelle Mounier-Geyssant ${ }^{1}$, Véronique Oury ${ }^{2}$, Lory Mouchot ${ }^{1}$, \\ Christophe Paris ${ }^{1,3}$ and Denis Zmirou-Navier*1,3
}

Address: ${ }^{1}$ INSERM Research unit ERI n ${ }^{\circ} 11$, Vandoeuvre-les-Nancy, France, ${ }^{2}$ INRS, Department of exposure assessment, Vandoeuvre-les-Nancy, France and 3School of Medicine, Nancy University; France

Email: Estelle Mounier-Geyssant - estellemounier@yahoo.fr; Véronique Oury - veronique.oury@inrs.fr;

Lory Mouchot - Lory.Mouchot@nancy.inserm.fr; Christophe Paris - christophe.paris@nancy.inserm.fr; Denis Zmirou-

Navier* - denis.zmirou@nancy.inserm.fr

* Corresponding author

Published: 07 August 2006

Environmental Health: A Global Access Science Source 2006, 5:23 doi:10.1 186/1476-069X-5-

23

This article is available from: http://www.ehjournal.net/content/5/I/23

(c) 2006 Mounier-Geyssant et al; licensee BioMed Central Ltd.

This is an Open Access article distributed under the terms of the Creative Commons Attribution License (http://creativecommons.org/licenses/by/2.0), which permits unrestricted use, distribution, and reproduction in any medium, provided the original work is properly cited.
Received: 12 April 2006

Accepted: 07 August 2006

\begin{abstract}
Background: Few studies have investigated exposure of hairdressing apprentices to airborne irritants. This study describes exposure levels of apprentices to chemical products used in hairdressing salons in relation with their activity.

Methods: Following a two stages study design, a group of 300 students completed a questionnaire on their work activities and environment. Among these, a group of 28 subjects volunteered to undergo personal exposure and workplace concentrations measurements over a work shift, during a cold and a hot season, with the agreement of the salon owners. Three chemical substances were studied (ammonia, hydrogen peroxide and persulfates) because they are respiratory tract irritants and because their concentrations could be quantified within a 5 to 8 hour shift period.
\end{abstract}

Results: Personal exposure values for $\mathrm{H}_{2} \mathrm{O}_{2}$ and $\mathrm{NH}_{3}$ (averages [standard deviations] are 0.05 [0.04] and 0.90 [0.76] mg. $\mathrm{m}^{-3}$, respectively) were greater than workplace ambient air concentrations (corresponding values of 0.04 [0.03] and 0.68 [0.42] mg.m $\mathrm{m}^{-3}$ ) for $\mathrm{H}_{2} \mathrm{O}_{2}$ and $\mathrm{NH}_{3}$, with no significant seasonal variation. By contrast, workplace concentrations of persulfates $(0.019$ [0.018] mg. $\left.\mathrm{m}^{-3}\right)$ were greater than personal exposure $\left(0.016[0.021] \mathrm{mg} \cdot \mathrm{m}^{-3}\right.$, a finding that is consistent with the fact that bleaching is more often undertaken by senior hairdressers. However, all exposure values were lower than the current TLV TWA values. This study also shows that over half of technical spaces where chemical substances used for dying, permanenting or bleaching are manipulated, have no ventilation system, and not even a door or a window opening outside.

Conclusion: The study hairdressing salons, on average, were small, the most probable reason why occupational hygiene measures such as appropriate ventilation were too seldom implemented. As a consequence, young apprentices and senior hairdressers experience substantial exposure to known airways irritants. 


\section{Background}

Occupational asthma is caused by sensitisation to an agent inhaled in the workplace. Onset of symptoms occurs after repeated exposure to chemicals and allergens in the work environment [1,2]. However, while many subjects experience exposure to agents that are known or suspected to provoke occupational asthma, only a fraction develop the condition $[3,4]$. Hairdressers are exposed to a variety of chemical agents as a result of usage of several hair cosmetic products such as hair dyes, permanent wave solutions and bleaches. Several constituents of hair care products are airway irritants and may induce respiratory conditions, including impairment of the pulmonary function and chronic bronchitis [3,5-12]. Hairdressing is described as an occupation at risk of asthma [4,13-17] and exposure to persulfate salts is involved in the induction of occupational asthma $[3,16,18,19]$.

Exposure studies in hairdressing salons are few. Given the variety of chemical substances that are used, some authors have measured tracer agents such as hydrogen peroxide, ammonia, volatile organic compounds (toluene, ethanol, isopropanol, ether, diaminotoluene, phenylenediamine) and carbon dioxide [20-23]. A 1992 study showed that workplace concentrations of phenylenediamine were below the ACGIH TLV-TWA [20]. Ethanol was used to categorize hairdressing workplace concentrations according to ventilation levels and intensity of technical services [21]. $\mathrm{CO}_{2}$ concentrations and levels for ammonia and ethanol were found high in absence of mechanical ventilation [22]. Installation of ventilation was shown to reduce measured levels of ethanol, isopropanol, toluene and ammonia [23].

Hairdressing apprentices experience exposure to the same substances during their training activities. Health studies among apprentices are sparse, however. Variability of the peak expiratory flow was assessed in Florence, Italy, across 10 days and was associated with job tasks, with influences of gender and smoking habits [24]. The prevalence of occupational asthma was $1.7 \%$ among 116 apprentices [25]. Hairdressing apprentices exhibited poorer lung function values than office apprentices [26]. In the framework of a study that aimed to assess how non asthmatic apprentices may develop airway inflammation in the course of their 3 years training, we undertook an exposure study to a selected number of airways irritants that are emitted into the air when using hairdressing products. We measured personal exposures and workplace concentrations during a work shift, with repeated sampling across two (hot and cold) seasons. This paper also describes the tasks that involve contact with such products during hairdressing activities.

\section{Methods}

With the collaboration of the administration of a large apprenticeship school in Nancy, north-east of France, we conducted a cross-sectional study in different hairdressing classes during the 2003-2004 and 2004-2005 academic years. This study had two steps. First, all apprentices following the first, second or third year of their training programme during this period were asked to complete, in the classroom, a questionnaire describing their work environment and activities. In a second step, volunteers were asked to participate to exposure measurements while at work in their hairdressing salon. The training programme typically encompasses a period of 3 weeks of practical work in the salon, followed by one week at school for practical and academic classes. Except for specific reasons (such as being fired by the hairdresser or because of resignation) an apprentice works in the same salon until he/ she graduates. Measurements were done during a regular workday, most of the time between Monday and Friday, depending upon agreement of the salon owners. With a view to assess seasonal variations, personal and workplace measurements were repeated over two seasons.

\section{Completion of questionnaires}

Questionnaire was designed after review of the literature, observations in several hairdressing salons and visits during the practical training classes in the apprenticeship school. It was validated by the school instructors and the heads of the local and regional hairdressing federations. A pilot study was undertaken during academic year 20022003 to check suitability of the questions for the study population.

In addition to retrieving information on personal characteristics, duration of a work shift, spatial organization of the salon and ventilation characteristics, the questionnaire requested the students to describe in detail their activities during a "standard" workday in the salon, "standard" meaning the most recent day with about the average daily number of customers over the last month.

\section{Exposure measurements in salons}

Because apprentices have little technical activities during the first year of training, and for schedule availability reasons, volunteers were mostly recruited among second graders. After apprentices declared their willingness to participate in this second stage of the study, authorization to undertake the measurement study was requested from the corresponding hairdressing salon owners or managers. Before returning a signed consent form, all study subjects were given a letter of invitation explaining the aim of the study and providing information on occupational asthma and its prevention. 
This exposure study involved personal measurements and fixed site monitoring in different salon locations: (i) in the technical space of the customer area (where customers sit during and after applying permanent waving, hair colour or bleaches), (ii) near the hair wash area and (iii) in the 'technical room' (i.e. where chemical mixtures are prepared, a location that is often in a rear part of the salon or in a specific room). Number of sampling locations depended upon the salon spatial characteristics. During air sampling, we collected information on relevant salons' characteristics (salon volume; existence of mechanical ventilation; means of natural ventilation - i.e. number of doors or windows opening directly outside the day measurements were done).

With a few exceptions, all apprentices contributed to two series of personal exposure and fixed site measurements: during the "cold season", from February to April, and during the "hot" season", from April to August. During the measurements, information was retrieved on usage of products that contained the selected study compounds. Among the variety of chemicals used in the hairdressing process, three compounds were chosen after review of the literature: ammonia $\left(\mathrm{NH}_{3}\right)$, hydrogen peroxide $\left(\mathrm{H}_{2} \mathrm{O}_{2}\right)$ and persulfates $\left(\mathrm{H}_{2} \mathrm{~S}_{2} \mathrm{O}_{8}\right)$. Hair dyeing formulations belong to three categories $[23,27]$ used for temporary, semi-permanent and permanent hair colouring. Colours of temporary dyes are readily removable with a single shampoo. The colouring effects of the semi-permanent dyes gradually fade over a period of 4 to 6 weeks, following the levels of hydrogen peroxide, ammonia and artificial colour molecules that have been applied. Permanent hair dyes, also called oxidative hair dyes, contain adjusting agents such ammonia and a stabilised solution of hydrogen peroxide. Oxidative hair dyes are resistant to fading by shampooing $[23,27]$. Hair bleaches contain ammonium, sodium and potassium persulfates. The active ingredients are persulfates which are mixed with an oxidant (hydrogen peroxide) just before usage. In order to improve the hair penetration, ammonia releasers such as ammonium chloride or ammonium phosphate are added. Permanent waving chemicals are of two types: alkaline or slightly acidic water solutions. They contain salts of thioglycolic acid and hydrogen peroxide. Like for hair bleaching, ammonia is added to enhance hair penetration $[23,27]$. As a result, ammonia and hydrogen peroxide are ingredients of permanent waves, hair dyes and hair bleaching. Persulfates are used in the formulation of bleaching powders. Selection of these three compounds was also decided after a feasibility study, both in one salon and in the apprenticeship school, showing they could be measured with good analytical sensitivity after personal sampling lasting 3 hours and more.

\section{- Air sampling}

Personal exposure measurements were done during a complete 5 to 8 hours work shift, the apprentices carrying the sampler installed in a rucksack; sampling heads were near the breathing zone. The Harvard Chempass sampler [28] was used during the first year measurements (winter and summer 2004; 8 measurements), when only two compounds were measured (persulfate and ammonia), a portable pump BGI (model 400) providing an air flow of $1.8 \mathrm{l} / \mathrm{min}$ in each head. For practical reasons (weight of the BGI pump), Gillian pumps were used the second year (winter and summer 2005), with a $1 \mathrm{l} / \mathrm{min}$ airflow for the three compounds. The total weight of the sampling devices was thus reduced, allowing to measure in parallel the three selected compounds. Data drawn with the two pumps were lumped together.

Environmental sampling was done by Gillian pumps with a $1 \mathrm{l} / \mathrm{min}$ airflow for the three compounds over the whole study period. Environmental sampling equipments were deposited at the beginning of the apprentice's work shift, in parallel to the personal exposure measurements. All samplers (environmental and personal exposure) were stopped during the lunch break in case it took place out of the salon.

\section{- Chemical analyses methods}

For analyses of hydrogen peroxide, quartz fibre filters were impregnated with $210 \mu$ l oxisulfate of titanium and quantification was done by colorimetry [29]. Persulfates were sampled on $37 \mathrm{~mm}$ Teflon filters of $1 \mu \mathrm{m}$ pore size and analyses were performed according to the BIA method [30]. Persulfates were determined with a ionchromatograph, Dionex model DX 600, LiChrospher column $100 \mathrm{RP}-18$ ( $5 \mu \mathrm{m}$, flow of $1 \mathrm{ml} / \mathrm{min}$ ) with the following eluents: tetrabutylammoniumhydroxide 0.005 mole/l, acid boric 0.0075 mole/l and acetonitril 22\%. Ammonia was collected on quartz filter impregnated by $\mathrm{H}_{2} \mathrm{SO}_{4}, 1.5$ $\mathrm{mol} / \mathrm{l}$. The analyses used ionchromatography, Dionex, model DX 600, Dionex CS12 column with, as eluents: carbonate/bicarbonate (2.7 milliMole of sodium carbonate, 0.3 milliMole of sodium bicarbonate) at a flow of $1 \mathrm{ml} /$ $\min$ [31]. Detection limits were $0.006 \mathrm{mg} / \mathrm{m}^{3}, 0.0005 \mathrm{mg} /$ $\mathrm{m}^{3}$ and $0.003 \mathrm{mg} / \mathrm{m}^{3}$ for $\mathrm{H}_{2} \mathrm{O}_{2}, \mathrm{H}_{2} \mathrm{~S}_{2} \mathrm{O}_{8}$ and $\mathrm{NH}_{3}$ respectively. The INRS laboratory where the chemical analyses were performed follows QA/QC procedures controlled by a dedicated national institution (Comité Français d'Accréditation, COFRAC).

\section{Sample size and statistical analysis}

Three hundred students completed the questionnaires in the apprenticeship school. An important drop occurred between this sample size and the number of those who contributed to the exposure measurements. Among the 35 subjects who volunteered, 12 employers declined partici- 
pation. Three cases were discarded: two because the hairdressing salon was too far, and one because the apprentice had to quit school for health reasons. In addition, three salons could not be visited in the hot season because of schedule constraints, leaving 28 ('cold season') and 25 ('hot season') measurements. Because the hairdressers had limited availability to answer the telephone calls, on average, 12 calls were necessary to obtain a final agreement and set a date for the measurements.

To compare exposures and air concentrations values we used the non parametric paired rank test because distributions were not Gaussian nor log-normal; average workplace concentrations were computed (with 2 to 3 data according to locations) after a check of their similarity. All values lower than the detection limit were set to half the detection limit; 2 (5.1\%) of the data were in this case for $\mathrm{H}_{2} \mathrm{O}_{2}$ personal exposure values, and none of the $\mathrm{NH}_{3}$ and persulfates personal exposures values (corresponding figures were respectively $15(9.6 \%), 0(0 \%)$ and $2(1.3 \%)$ for $\mathrm{H}_{2} \mathrm{O}_{2}, \mathrm{NH}_{3}$ and persulfates workplace concentrations). To study the influence of salon characteristics on exposures, we used multivariate general linear models where the salon volume, presence of ventilation devices or natural ventilation during the sampling period (i.e. door or windows opened outside) and season were the explanatory variables. Questionnaires data were input with Epidata. Statistical analysis was carried out using the SASstatistical package and Statgraphics.

\section{Results}

\section{Study population and work environment}

Apprentices were almost all females (table 1). Since most apprentices were in salons for both men and women (one was in men-only and 4 were in women-only facilities), the following results will not differentiate salons according to gender customers. Table 2, based on questionnaires data, shows the distribution of declared time spent at work according to the training level with, as expected, longer shifts among second and third graders.

There were 3 types of spatial settings: 144 apprentices declared their salon was organized with specific areas (haircut and brushing spot; shampoo spot; technical spot where creams and solutions were prepared) within a single volume; 51 reported different rooms for these activities; and 102 were in a homogeneous single space with no area differentiation. One third of customer spaces and two thirds of technical spaces, when existing, had no ventilation device (fan, air conditioning or other type of venting, like ceiling fan) (table 3 ). The size of the salons where measurements were carried out spanned from 52.5 to 288 $\mathrm{m}^{3}$ (average 143.68 [sd:62.4] $\mathrm{m}^{3}$ ).

The tasks that are associated with manipulation of chemicals are described in table 4 which exhibits how frequent these tasks are accomplished during a typical day, as reported by questionnaires. Data are split according to training level; corresponding figures for apprentices who volunteered to participate to the exposure measurements are in the last column. Tasks frequencies varied markedly according to training year (all p values after Kruskal-Wallis tests were smaller than 0.03), except for rinsing hair bleaches $(p=0.42)$. Daily numbers of services using chemicals for permanent waves and of hair colour rinsing are greater, on average, among second year students, while preparing and applying hair colour and hair bleaches is more frequent among third graders.

\section{Exposure measurements}

As shown in table 1, apprentices who participated in the exposure study were mostly in their second year of training. Table 5 presents personal exposure levels along with concentrations of the 3 measured chemicals in different locations of the hairdressing salons. Personal exposures to $\mathrm{H}_{2} \mathrm{O}_{2}\left(\mathrm{n}=39\right.$; mean 0.051 [sd: 0.042 ] $\left.\mathrm{mg} / \mathrm{m}^{3}\right)$ and $\mathrm{NH}_{3}$ $(\mathrm{n}=52 ; 0.900$ [sd: 0.762$\left.] \mathrm{mg} / \mathrm{m}^{3}\right)$ are greater than average workplace concentrations $(0.037$ [sd: 0.031$] \mathrm{mg} / \mathrm{m}^{3}$ and 0.677 [sd: 0.425 ] mg/m $\mathrm{m}^{3}$, respectively) (winter and summer data altogether, because they did not differ: all paired test $p$ values being equal to or greater than 0.11 ). The opposite holds true for $\mathrm{H}_{2} \mathrm{~S}_{2} \mathrm{O}_{8}(\mathrm{n}=51 ; 0.016$ [sd: 0.021] $\mathrm{mg} / \mathrm{m}^{3}$ and 0.019 [sd: 0.018 ] $\mathrm{mg} / \mathrm{m}^{3}$, respectively). We found no significant association between salon volumes or ventilation means and personal exposures, irrespective of the measured compound (all p values greater than $0.13)$.

Table I: Description of the study population.

\begin{tabular}{lcc}
\hline & All apprentices $(\mathrm{n}=300)$ & Exposure volunteers $(\mathrm{n}=28)$ \\
\hline Gender & & $27(96,4)$ \\
Female & $293(97,7)$ & $1(3,6)$ \\
Male & $7(2,3)$ & $4(14,3)$ \\
Training level & $73(24.3)$ & $17(60,7)$ \\
$\quad$ First year & $141(47.0)$ & $7(25.0)$ \\
Second year & $86(28.7)$ & \\
Third year & & \\
\hline
\end{tabular}


Table 2: Duration of daily shift according to apprenticeship training level.

\begin{tabular}{|c|c|c|c|c|}
\hline & & {$[6-8$ h [(\%) } & [8-10 h [(\%) & {$[10-12 \mathrm{~h}](\%)$} \\
\hline & First year $(n=73)$ & $37(50.7)$ & $30(4 \mid . I)$ & $5(6.9)$ \\
\hline \multirow[t]{2}{*}{ CAP } & Second year $(n=|4|)$ & $42(29.8)$ & $87(61.7)$ & $12(8.5)$ \\
\hline & Third year $(n=86)$ & $23(26.8)$ & $53(61.6)$ & $10(11.6)$ \\
\hline
\end{tabular}

\section{Discussion}

Although a larger sample for the exposure study population was expected, achieving this objective was difficult for many reasons. First, occupational health is not regarded as of serious concern in this population of teenagers. Appreciation of respiratory diseases prevention was low among apprentices, an observation also made by Wong et al among hairdressing students [32]. Second, many apprentices were reluctant to accept participation because they anticipated refusal or feared rebuttal by their boss. Third, the constraints posed to volunteers and to the hairdressing managers cannot be underestimated, including with respect to the salon costumers. For these reasons, it was not possible to sample participating salons among different categories of facilities (small, large; within commercial malls or in solo), as we had planned. Our experience, however, is that the types of facilities and indoor environments of hairdressing salons do not vary greatly in the Lorraine region. Hence, while this is not a random sample, exposure data can be viewed as indicative of typical values currently found in such facilities.

Questionnaires were designed to obtain descriptive information on apprentices' work conditions in hairdressing salons. In order to minimize recall bias, individual tasks we explored for a typical weekday, to be chosen within the ongoing week; it was frequently the previous work day. We did not attempt to study the busiest day, as Labreche et al did [33]; however, the number of tasks that are accomplished in our study is in the same order as those they reported. Hair colouring is the task most often practiced among the chemical services, more than permanente waving and hair bleaching. According to Kersemaekers, however, hairdressers tend to overestimate their work load; also, they do not know accurately the type of ventilation in their facility [34].
While the observed greater personal exposure values, as opposed to $\mathrm{H}_{2} \mathrm{O}_{2}$ and $\mathrm{NH}_{3}$ workplace concentrations, were expected, in accord with the 'personal cloud' concept, we found opposite results for $\mathrm{H}_{2} \mathrm{~S}_{2} \mathrm{O}_{8}$. This may be explained by two reasons. Apprentices were less involved in bleaching than in hair dyeing and permanenting (table 4) because, being a more technical task (both for bleaching mixture preparation and its application), it is more often accomplished by senior hairdressers. Further, workplace air samplers were located in a place deemed representative of the area to be monitored. Hence, in this case of activity imbalance within the salon work team, fixed samplers were liable to be more influenced by the tasks executed by senior hairdressers than by the study apprentice. This was not the case for compounds associated with hair dyes and permanenting, because these tasks were frequently accomplished by apprentices.

Comparison of exposure and concentrations results across the literature should be done with caution because time and space sampling procedures, measurement techniques and methods of analyses are not always comparable. Other differences across studies may be due to exposure sampling designs and stem from the fact that working conditions may vary across study locations. In the study by Hollund et al., for example, measurements were done during the phase of preparation of the technique, with a view to assess peak concentrations, also taking into account certain parameters of ventilation [23]. We found that more than half of technical areas did not have ventilation systems nor did they open outside (through a door or a window). For the American Society of Heating Refrigerating and Air Conditioning Engineers, ventilation rates in beauty salons should ensure values of 20 cubic feet/ minute/person, and $7.5 \mathrm{cfm} /$ person for barber shops (minimum ventilation rates breathing zone) [35].

Table 3: Proportion of salons with no ventilation nor direct opening outside, by salon area.

\begin{tabular}{|c|c|c|c|}
\hline & No ventilation & No door opening outside & No window opening outside \\
\hline Customers space & $32.8(259)^{a}$ & $4.4(298)^{\mathrm{a}}$ & $53.2(297)^{\mathrm{a}}$ \\
\hline Technical space & $66.1(218)^{\mathrm{a}}$ & $51.9(262)^{\mathrm{a}}$ & $63.3(253)^{\mathrm{a}}$ \\
\hline
\end{tabular}

a: number of questionnaires completed. 
Table 4: Daily frequency of activities associated with manipulation of chemicals (in \% of respondents).

\begin{tabular}{|c|c|c|c|c|c|}
\hline & & $\begin{array}{l}\text { First year } \\
(\mathrm{n}=73)^{\mathrm{a}} \\
(\max =68)^{\mathrm{b}} \\
(\min =59)^{\mathrm{c}}\end{array}$ & $\begin{array}{l}\text { Second year } \\
(\mathrm{n}=141)^{\mathrm{a}} \\
(\max =137)^{\mathrm{b}} \\
(\min =131)^{\mathrm{c}}\end{array}$ & $\begin{array}{l}\text { Third year } \\
(\mathrm{n}=86)^{\mathrm{a}} \\
(\max =86)^{\mathrm{b}} \\
(\min =82)^{\mathrm{c}}\end{array}$ & $\begin{array}{c}\text { Volunteers } \\
(\mathrm{n}=28)^{\mathrm{a}} \\
(\max =26)^{\mathrm{b}} \\
(\min =24)^{\mathrm{c}}\end{array}$ \\
\hline \multirow[t]{4}{*}{ Application of permanent waving } & 0 per day & 27.9 & 18.2 & 14.5 & 23.1 \\
\hline & {$[1-2]$} & 45.9 & 38.6 & 49.4 & 46.2 \\
\hline & {$[3-5]$} & 24.6 & 34.9 & 32.5 & 26.9 \\
\hline & {$[6-15]$} & 1.6 & 8.3 & 3.6 & 3.8 \\
\hline \multirow[t]{4}{*}{ Rinsing permanent waving } & 0 per day & 3.2 & 6.7 & 10.6 & 4.0 \\
\hline & {$[1-2]$} & 62.9 & 38.5 & 47.1 & 52.0 \\
\hline & {$[3-5]$} & 30.7 & 45.9 & 37.6 & 40.0 \\
\hline & {$[6-15]$} & 3.2 & 8.9 & 4.7 & 4.0 \\
\hline \multirow[t]{4}{*}{ Applying neutralizing agent } & 0 per day & 9.8 & 8.3 & 10.5 & 4.2 \\
\hline & {$[1-2]$} & 63.9 & 39.8 & 46.5 & 54.1 \\
\hline & {$[3-5]$} & 24.6 & 42.9 & 34.9 & 37.5 \\
\hline & {$[6-15]$} & 1.7 & 9.0 & 8.1 & 4.2 \\
\hline \multirow[t]{4}{*}{ Preparing hair colour } & 0 per day & 17.2 & 9.8 & 1.2 & 4.0 \\
\hline & {$[1-4]$} & 32.8 & 22.5 & 25.9 & 4.0 \\
\hline & {$[5-9]$} & 35.9 & 37.6 & 40.0 & 64.0 \\
\hline & {$[10-25]$} & 14.1 & 30.1 & 32.9 & 28.0 \\
\hline \multirow[t]{4}{*}{ Applying hair colour } & 0 per day & 10.3 & 3.6 & 0 & 3.8 \\
\hline & {$[1-4]$} & 48.5 & 33.6 & 26.5 & 30.8 \\
\hline & {$[5-9]$} & 32.4 & 36.5 & 47.0 & 38.5 \\
\hline & {$[10-22]$} & 8.8 & 26.3 & 26.5 & 26.9 \\
\hline \multirow[t]{4}{*}{ Rinsing hair colour } & 0 per day & 0 & 1.5 & 1.2 & 0 \\
\hline & {$[1-4]$} & 32.8 & 18.7 & 20.2 & 15.4 \\
\hline & {$[5-9]$} & 47.8 & 34.3 & 53.6 & 50.0 \\
\hline & {$[10-25]$} & 19.4 & 45.5 & 25.0 & 34.6 \\
\hline \multirow[t]{4}{*}{ Preparing hair bleaches } & 0 per day & 45.9 & 23.9 & 16.9 & 12.0 \\
\hline & {$[1-2]$} & 22.9 & 34.6 & 40.9 & 44.0 \\
\hline & {$[3-6]$} & 14.8 & 24.6 & 24.1 & 28.0 \\
\hline & {$[7-20]$} & 16.4 & 16.9 & 18.1 & 16.0 \\
\hline \multirow[t]{4}{*}{ Applying hair bleaches } & 0 per day & 64.4 & 34.4 & 23.2 & 32.0 \\
\hline & {$[1-2]$} & 22.0 & 40.5 & 39.0 & 44.0 \\
\hline & {$[3-6]$} & 6.8 & 19.8 & 25.6 & 20.0 \\
\hline & {$[7-20]$} & 6.8 & 5.3 & 12.2 & 4.0 \\
\hline \multirow[t]{4}{*}{ Rinsing hair bleaches } & 0 per day & 31.7 & 15.3 & 14.3 & 24.0 \\
\hline & {$[1-2]$} & 30.2 & 43.5 & 42.9 & 48.0 \\
\hline & {$[3-6]$} & 22.2 & 30.5 & 28.6 & 24.0 \\
\hline & {$[7-20]$} & 15.9 & 10.7 & 14.3 & 4.0 \\
\hline
\end{tabular}

a: numbers apprentices by level; b: maximum number of respondents for the set of questions; c: minimum number of respondents for the set of questions.

Our results for personal exposures to ammonia show maximum values similar to those described by Hollund $e t$ al for dyeing and waving $\left(4.4 \mathrm{mg} / \mathrm{m}^{3}\right.$, versus $4.5 \mathrm{mg} / \mathrm{m}^{3}$ during our 'cold period') but Hollund et al found levels up to $10 \mathrm{mg} / \mathrm{m}^{3}$ during bleaching, in absence of exhaust ventilation. Also, while average exposure values were greater than in our study, workplace ambient concentrations in both studies are close [23]. The study by Leino et al aimed at measuring peak concentrations during the process of dyeing, permanenting and bleaching; it shows values 1.3 times smaller than our maximum personal exposure measurements [27]. Although the 2 minutes spot exposure measurements found by Van der Wal are very high compared to our values, their ambient air measurements are similar to ours [22]. It should be noted that all these results were below the French and Belgium TLVs for ammonia (7 and $14 \mathrm{mg} / \mathrm{m}^{3}$, respectively) [36,37], the NIOSH TWA-REL for ammonia $\left(18 \mathrm{mg} / \mathrm{m}^{3}\right)$ and the OSHA TWA-PEL (35 mg/m³) [38].

Average personal exposures to $\mathrm{H}_{2} \mathrm{O}_{2}$ in our study are 1.4 times lower than those found by Van der Wal et al during the process of colour rinsing, and 2.8 times lower during bleaching (exposures were 2 minutes spot measurements in the Van der Wal et al study). This study also describes greater exposure figures during waiving $\left(0.14-1.4 \mathrm{mg} / \mathrm{m}^{3}\right.$, during 2 minutes spot exposure measurements) [22]. Average air concentrations during a shift, however, are 
Table 5: Personal exposures and workplace concentrations for ammonia, hydrogen peroxide and persulfates in different salon areas.

\begin{tabular}{|c|c|c|c|}
\hline & $\mathrm{H}_{2} \mathrm{O}_{2}$ & $\mathbf{N H}_{3}$ & $\mathrm{H}_{2} \mathrm{~S}_{2} \mathbf{O}_{8}$ \\
\hline \multirow[t]{3}{*}{ Personal exposure } & $(n=39)^{a}$ & $(n=53)$ & $(n=52)$ \\
\hline & $0.05^{\mathrm{b}}(0.04)^{\mathrm{c}}$ & $0.90(0.76)$ & $0.02(0.02)$ \\
\hline & {$[0.003 *-0.18]^{\mathrm{d}}$} & [0.02-4.49] & {$[0.001-0.12]$} \\
\hline \multirow[t]{3}{*}{ Technical area in the customer salon (permanenting, dyeing, bleaching with the customers) } & $(n=53)$ & $(n=52)$ & $(n=52)$ \\
\hline & $0.04(0.03)$ & $0.72(0.49)$ & $0.02(0,02)$ \\
\hline & {$[0.003 *-0.18]$} & [0.13-3.03] & {$[0.00025 *-0.1]$} \\
\hline \multirow[t]{3}{*}{ Shampoo area } & $(n=5 I)$ & $(n=5 I)$ & $(n=5 I)$ \\
\hline & $0.03(0.03)$ & $0.65(0.40)$ & $0.02(0,02)$ \\
\hline & {$[0.003 *-0.13]$} & [0.09-2.39] & {$[0.00025 *-0.13]$} \\
\hline \multirow[t]{3}{*}{ Technical room (mixing the chemicals for permanenting, dyeing and bleaching) } & $(n=52)$ & $(n=52)$ & $(n=52)$ \\
\hline & $0.04(0.05)$ & $0.66(0.45)$ & $0.02(0,02)$ \\
\hline & {$[0.003 *-0.34]$} & {$[0.13-2.64]$} & {$[0.002-0.08]$} \\
\hline \multirow[t]{3}{*}{ Average of ambient air concentrations in each salon } & $(n=53)$ & $(n=52)$ & $(n=52)$ \\
\hline & $0.04(0.03)$ & $0.68(0.42)$ & $0.02(0,02)$ \\
\hline & {$[0.003 *-0.15]$} & {$[0.13-2.69]$} & {$[0.002-0.08]$} \\
\hline
\end{tabular}

a: Each cell comprises the number of samples; b: the arithmetic mean; c: standard deviate; $\mathrm{d}$ : [min-max] (in $\mathrm{mg} / \mathrm{m}^{3}$ )

* These min. figures were set to half the detection limit (see chapter materials and methods).

between 2 times lower than our results, respectively in winter and summer [22]. The German BIA designed a hairdressing salon and performed a quasi-experimental study. The sampling site close to the armchair showed a maximum $\mathrm{H}_{2} \mathrm{O}_{2}$ value 1.6 times higher than ours in customer salons. Also, the maximum concentrations measured in the hairdressing laboratory were 2.4 times greater than our maximum value in technical areas, during the winter period measurements [30]. French and Belgium TLVs, NIOSH REL TWA, OSHA PEL TWA for $\mathrm{H}_{2} \mathrm{O}_{2}$ are 1.5 and $1.4 \mathrm{mg} / \mathrm{m}^{3}$, respectively [36-38].

Our maxima personal exposure results during summer are 3.8 times greater than the peak values found by Leino et al during mixing of bleaching powder. Our average workplace concentrations are also respectively 6.6 and 21.1 times higher than those found in the small and large salons they studied [27]. These results are worrisome since persulfate salts are important asthma causal agents $[3,16,18,19,27]$. On the other hand, results from the BIA study exceed our maxima workplace concentrations [30]. It should be noted, however, that the former stem from short periods measurements, focused in particular when mixtures of hairdressing products were made, while our data correspond to shift averages over all daily activities. To our knowledge, there is no TLV for persulfates as a whole; a persulfate ammonium TLV of $0.1 \mathrm{mg} / \mathrm{m}^{3}$ has been set by the US ACGIH and in Belgium [37,39].

\section{Conclusion}

Ventilation is not frequent in the study hairdressing salons. Manipulation of bleaching products, among other chemical substances used in the hairdressing process, yields exposure to airways irritants. Although lower than current occupational limit values, these exposures might be of health significance. These findings suggest that further occupational hygiene progresses may result from a combination of efforts dealing with safer products presentation, improvements in facility ventilation equipment, and information of hairdresser, including young apprentices during their training, as to potential hazards in the workplace.

\section{Abbreviations \\ $\mathrm{NH}_{3}=$ Ammonia \\ $\mathrm{H}_{2} \mathrm{O}_{2}=$ Hydrogen peroxide \\ $\mathrm{H}_{2} \mathrm{~S}_{2} \mathrm{O}_{8}=$ Persulfates}

\section{Competing interests}

The author(s) declare that they have no competing interests.

\section{Authors' contributions}

EMG coordinated the study, designed the questionnaire, conducted field investigations and performed the statistical analysis. She is the main author of the manuscript. VO performed all chemical analyses. LM contributed to the statistical analysis. CP was an advisor for the study design and contributed to writing the paper. DZN directed the study and supervised writing of the manuscript. All authors read and approved the final manuscript.

\section{Acknowledgements}

Contribution of the Pollutants Measurement Department (Département Métrologie des Polluants) of INRS (Institut National de Recherche et de Sécurité), for study design and chemical analyses, is highly appreciated. Lahoucine Benamghar contributed to the data analysis. The authors express their gratitude to the apprentice volunteers who participated in this study, along with the salon owners. They thank the Nancy-Laxou 
apprenticeship school teachers and head, and the local and regional hairdressing federations (Fédération Régionale de la Coiffure de Lorraine, Fédération Départementale de la Coiffure de Meurthe et Moselle, Organisation Professionnelle des Coiffeurs de la Meuse, Union des Corporations des Patrons Coiffeurs et Coiffeuses de la Moselle, Fédération Départementale de la Coiffure des Vosges).

This study was performed with grants from AFSSE (contract RD-2003-04), the French Ministry of Labour (2002 Health and Occupation call for proposal), and the regional Social Security office (CRAM Nord-Est). L'Oreal also provided financial support. Estelle Mounier-Geyssant was recipient of a doctoral grant from INSERM and the Lorraine Region.

\section{References}

I. Ameille J, Pauli G, Calastreng-Crinquand A, Vervloët D, Iwatsubo $Y$, Popin E, Bayeux-Dunglas MC, Kopferschmitt-Kubler MC: Reported incidence of occupational asthma in France, 1996-99: the ONAP programme. Occup Environ Med 2003, 60:| $36-14 \mid$.

2. Malo JL, Chan-Yeung M: Occupational asthma. J Allergy Clin Immunol 200I, I08(3):317-328.

3. Moscato G, Pignatti P, Yacoub MR, Romano C, Spezia S, Perfetti L: Occupational asthma and occupational rhinitis in hairdressers. Chest 2005, I 28(5):3590-3598.

4. Blainey AD, Ollier S, Cundell D, Smith RE, Davies RJ: Occupational asthma in a hairdressing salon. Thorax 1986, 4I(I):42-50.

5. Borelli S, Wüthrich B: Immediate and delayed hypersensitivity to ammonium persulfate. Allergy 1999, 54(8):893-894.

6. Parra FM, Igea JM, Quirce S, Ferrando MC, Martin JA, Losada E: Occupational asthma in a hairdresser caused by persulphate salts. Allergy 1992, 47:656-660.

7. Schwartz HJ, Arnold JL, Strohl KP: Occupational allergie rhinitis in the hair care industry: reactions to permanent wave solutions. J Occup Med 1990, 32(5):473-475.

8. NIOSH: Health hazard determination report: Radiant Lady Beauty Salon, Inc., Denver, CO. Cincinnati, OH: U.S. Department of Health and Human Services, Public Health Service, National Institute for Occupational Safety and Health, NIOSH Report No.75-I28-262 1976.

9. Heacock HJ, Rivers JK: Occupational diseases of hairdressers. Can J Public Health I 986, 77(2): I09-I I3.

10. Pepys J, Hutchcroft BJ, Breslin AB: Asthma due to inhaled agentspersulphate salts and henna in hairdressers. Clin Allergy 1976, 6(4):399-404.

11. Slater T, Bradshaw L, Fishwick D, Cheng S, Kimbell-Dunn M, Erkinjuntti-Pekkanen R, Douwes J, Pearce N: Occupational respiratory symptoms in New Zealand hairdressers. Occup Med 2000, 50(8):586-590.

12. Leino T, Tammilehto L, Luukkonen R, Nordman H: Self reported respiratory symptoms and diseases among hairdressers. Occup Environ Med 1997, 54:452-455.

13. Akpinar-Elci M, Cimrin AH, Elci OC: Prevalence and Risk Factors of Occupational Asthma Among Hairdressers in Turkey. J Occup Environ Med 2002, 44(6):585-590.

14. Leino T, Tammilehto L, Paakkulainen $H$, Orjala $H$, Nordman $H$ : Occurrence of Asthma and Chronic Bronchitis Among Female Hairdressers. J Occup Environ Med 1997, 39(6):534-539.

15. Schwaiblmair M, Vogelmeier C, Fruhmann G: Occupational asthma in hairdressers: results of inhalation tests with bleaching powder. Int Arch Occup Environ Health 1997, 70:419-423.

16. Moscato G, Galdi E: Asthma and hairdressers. Curr Opin Allergy Clin Immunol 2006, 6(2):91-95.

17. Hollund BE, Moen BE, Lygre SH, Florvaag E, Omenaas E: Prevalence of airway symptoms among hairdressers in Bergen, Norway. Occup Environ Med 200I, 58:780-785.

18. Munoz X, Cruz MJ, Orriols R, Bravo C, Espuga M, Morell F: Occupational asthma due to persulfate salts : diagnosis and followup. Chest 200I, I 23(6):2I 24-2I 29.

19. Munoz X, Cruz MJ, Orriols R, Torres F, Espuga M, Morell F: Validation of specific inhalation challenge for the diagnosis of occupational asthma due to persulphate salts. Occup EnvironMed 2004, 61 (10):86I-866.

20. Gagliardi L, Ambroso M, Mavro J, Furno F, Discalzi G: Exposure to paraphenylendiamine in hairdressing parlours. Int $J$ Cosmet $\mathrm{Sci}$ 1992, |4:|9-3|.
21. Van Muiswinkel JV, Kromhout H, Onos T, Kersemaekers W: Monitoring and modelling of exposure to ethanol in hairdressing salons. Ann occup Hyg 1997, 4 I (2):235-247.

22. Van der Wal JF, Hoogeveen AW, Moons AMM, Wouda P: Investigation on the exposure of hairdressers to chemical agents. Environ Int 1997, 23(4):433-439.

23. Hollund BE, Moen BE: Chemical Exposure in Hairdressers Salons: Effect of Local Exhaust Ventilation. Ann occup Hyg 1998, 42(4):277-281.

24. Arcangeli G, Baldasseroni A, Palmi S, Bianchi A: [Reversible pulmonary response to irritating substances: study on a population of apprentice hairdressers.]. Prevenzione oggi 1999, XI(4):3-33.

25. Gülmez Ý, Çetinkaya F, Oymak FS, Demir R, Ozesmi M: Occupational asthma among hairdresser's apprentices [abstracts]. Europ Respir J Suppl 1998, 28:333s-334s.

26. Iwatsubo Y, Matrat M, Brochard P, Ameille J, Choudat D, Conso F, Coulondre D, Garnier R, Hubert C, Lauzier F, Romano MC, Pairon JC: Healthy worker effect and changes in respiratory symptoms and lung function in hairdressing apprentices. Occup Environ Med 2003, 60:83I-840.

27. Leino T, Kähkönen E, Saarinen L, Henriks-Eckerman M-L, Paakkulainen $\mathrm{H}$ : Working Conditions and Health in Hairdressing Salons. Appl Occup Environ Hyg 1999, 14:26-33.

28. Demokritou P, Kavouras IG, Ferguson ST, Koutrakis P: Developpement and laboratory performance evaluation of a personal multipollutant sampler for simultaneous measurements of particulate and gaseaous pollutants. Aerosol Sci Technol 200I, 35:74I-752.

29. Métropol. Fiche 047 : Peroxyde d'hydrogène [http:// www.inrs.fr/]

30. Ermittlung der Atemwegsbelastungen durch luftfremde Stoffe an Friseurarbeitsplätzen. Abschlussbericht. BIA, Bericht Nr.: 36/199920I 17. Sankt Augustin; :28. 29.10.1999

3I. Métropol. Fiche 013 : Ammoniac et sels d'ammonium [http:/ /www.inrs.fr/]

32. Wong RH, Chien HL, Luh DL, Lin WH, Wang YC, Cho CY: Correlation Between Chemical-Safety Knowledge and Personal Attitudes Among Taiwanese Hairdressing Students. Am J Ind Med 2005, 47(I):45-53.

33. Labreche F, Forest J, Trottier M, Lalonde M, Simard R: Characterization of chemical exposures in hairdressing salons. Appl Occup Environ Hyg 2003, I 8( I 2): I0 I4- 1021.

34. Kersemaekers WM, Verheijen N, Kromhout H, Roeleveld N, Zielhuis $\mathrm{GA}$ : Assessment of exposure to solvents among hairdressers: reliability of a classification scheme and questionnaire. Occup Environ Med 1998, 55:37-42.

35. American Society of Heating, Refrigerating and Air-Conditioning Engineers (ASHRAE). In ANSIIASHRAE Standard 62.I2004 - Ventilation for Acceptable Indoor Air Quality (ANSI Approved) Atlanta, GA; 2004.

36. Institut National de Recherche et de Sécurité INRS: Valeurs limites d'exposition professionnelle aux agents chimiques en France. ND 2098. Note Documentaire. Mise à jour février 2005. France 2005.

37. Arrêté royal du II mars $\mathbf{2 0 0 2}$ relatif à la protection de la santé et de la sécurité des travailleurs contre les risques liés aux agents chimiques sur le lieu de travail (MB | 4.3.2002 Ed. 2;erratum M.B. 26.6.2002, Ed. 2;erratum M.B. 4.12.2002). Annexe I. Valeurs limites d'exposition professionnelle

38. Department of health and human services. Centers for Disease Control and Prevention. National Institute for Occupational Safety and Health. In Niosh pocket guide to chemical hazards DHHS (NIOSH) Publication No. 2005-I49; 2005.

39. American Conference of Governmental Industrial Hygienists ACGIH: Annual Reports of the Committees on TLVs $®$ and BEls@ for Year 2005 Cincinnati, OH; 2005. 